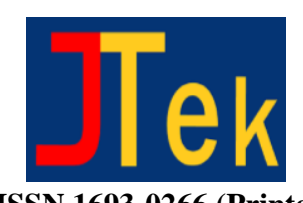

ISSN 1693-0266 (Printed)

\title{
Simulasi Sebaran Pencemaran BTEX di Daerah Sekitar SPBU yang Mengalami Kebocoran Tangki Timbun BBM
}

\author{
Lukman Nulhakim ${ }^{1, \text { b) }}$ dan Dody Guntama ${ }^{2, \text { a) }}$ \\ Teknik Kimia Fakultas Teknologi Industri Universitas Jayabaya \\ Jalan Raya Bogor Km. 28,8 Jakarta Timur \\ a)dodysopril@gmail.com \\ b)Corresponding author: lukman@ftijayabaya.ac.id
}

\begin{abstract}
The carogenic compounds contained in fuel oil are Benzene, Toluene, Ethylbenzen, Xylene (BTEX) where BTEX will cause adverse effects from the polluting environment. The common health impact of being exposed to BTEX is the disruption of the central nervous system. The potential for environmental pollution by BTEX can occur due to leakage at underground fuel storage tanks in Gasoline Station. In this study simulation of BTEX pollution was carried out due to leakage at underground fuel storage tank around the area of Gasoline Station 44.5522.10 Yogyakarta. The simulation is carried out using a mathematical model that involves advection, biodegradation rate, diffusion in 2 dimensions. The results showed variables such as leakage discharge, leakage area and air flow velocity did not affect a wide area so that these variables affected contaminants in each region. The area covered by Benzene is $\pm 560 \mathrm{~m}^{2}$, Toluene is $\pm 354 \mathrm{~m}^{2}$, Ethylbenzene is $\pm 234 \mathrm{~m}^{2}$, Xylene is $\pm 336 \mathrm{~m}^{2}$.
\end{abstract}

\begin{abstract}
Abstrak
Senyawa karsiogenik yang terdapat dalam Bahan Bakar Minyak (BBM) adalah Benzen, Toluen, Ethylbenzen, Xylen (BTEX) dimana BTEX akan menimbulkan dampak buruk apabila mencemari lingkungan. Dampak kesehatan yang umum terjadi karena terpapar oleh BTEX adalah terganggunya sistem syaraf pusat. Potensi pencemaran lingkungan oleh BTEX dapat terjadi karena kebocoran tangki timbun BBM di Stasiun Pengisian Bahan Bakar Umum (SPBU). Pada penelitian ini dilakukan simulasi pencemaran BTEX yang disebabkan kebocoran tangki timbun BBM di sekitar area SPBU 44.552.10 Yogyakarta. Model matematika yang disimulasi melibatkan adveksi, laju biodegradasi, difusi secara 2 dimensi. Hasil simulasi menunjukkan bahwa variabel seperti debit kebocoran, luas kebocoran tangki timbun dan kecepatan aliran air tanah tidak mempengaruhi luas area yang tercemar, namun variabel tersebut mempengaruhi konsentrasi kontaminan di setiap area. Luas area yang tercamar Benzen adalah $\pm 560 \mathrm{~m}^{2}$, Toluen adalah $\pm 354 \mathrm{~m}^{2}$, Ethylbenzen adalah $\pm 234 \mathrm{~m}^{2}$, Xylen adalah $\pm 336 \mathrm{~m}^{2}$.
\end{abstract}

Keywords: BTEX, Simulation, Gasoline Station, Ground Water, Leakage. 


\section{Pendahuluan}

Bahan Bakar Minyak (BBM) merupakaan suatu kebutuhan pokok bagi manusia saat ini. BBM umumnya digunakan untuk sumber bahan bakar untuk berbagai moda transfortasi. Dimana pada tahun 2015 tingkat kebutuhan BBM jenis bahan bakar fosil di Indonesia mencapai 1,5 juta barel per hari [1]. Namun disisi lain penggunaan BBM ini dapat memberikan dampak negatif yaitu pencemaran lingkungan yang dapat berupa pencemaran secara tidak langsung ataupun langsung. Pengcemaran secara tidak langsung dapat terjadi ketika BBM dibakar dalam kendaraan bermotor yang menghasilkan gas berbahaya yaitu Karbon Monoksida (CO), Sulfur Monoksida (SOx), dan Nitrogen Oksida (NOx). Dampak pencemaran gas $\mathrm{CO}$, SOx, dan $\mathrm{NOx}$ adalah penyakit jantung, penyakit pernapasan, dan bronkitis kronis [2]. Pencemaran langsung dapat diakibatkan karena kebocoran bahan bakar baik dari pipa penyaluran bahan bakar ataupun tangki penampungan BBM di Stasiun Pengisian Bahan Bakar Umum (SPBU). Pada Tahun 2018 Pemerintah Indonesia menyatakan darurat bencana karena kebocoran BBM dari pipa di Balikpapan Kalimantan Timur. Kebocaran ini menyebabkan kerusakan lingkungan dan kematian 5 Nelayan akibat terbakarnya tumpahan BBM yang bersumber dari kebocoran tersebut [3]. Kebocoron BBM dari tanki penampungan BBM dapat mencemari tanah dan air tanah warga secara langsung. Beberapa penelitian telah dilakukan untuk mengkaji potensi pencemaran kebocoran BBM terhadap lingkungan. Potensi kebocoran tangki timbun di SPBU di Yogyakarta, dilakukan dengan menguji air tanah di 4 SPBU di Yogyakarta. Sampel air diambil untuk dianalisis kandungan hidrokarbonnya. Hasil dari analisis menyimpulkan hanya 1 sumber air tanah di sekitar SPBU yang mengandung senyawa hidrokarbon, namun jenis hidrokarbon pada sampel berbeda dengan pada BBM [4]. Dampak kembocoran tangki timbun BBM di wilayah pemukiman sekitar SPBU nomor 44.552.10 Yogyakarta terhadap sumur warga diteliti, dimana faktor fisik seperti kedalaman muka air tanah dari dasar tangki, daya serap di atas muka air tanah permeabilitas akifer, kemiringan muka air tanah dan jarak horizontal dari sumber pencemar. Data pengukuran faktor fisik di atas digunakan untuk mensimulasikan konsentrasi BBM disekitar tangki timbun, dari total 80 titik sampling sumur di sekitar SPBU nomor 44.552.10 Yogyakarta diindikasikan 58,75\% tercemar BBM [5]. Penelitian ini ditujukan untuk melengkapi peneltian terdahulu yakni dengan menggunakan permodelan matematika untuk proses kebocoran tangki timbun.

Pemodelan matematika dapat membantu peneliti untuk memprediksi dan mensimulasikan proses yang terjadi dilapangan sebelum proses sampling dilakukan, sehingga didapat hasil penelitian yang akurat. Simulasi yang dilakukan pada penelitian ini menggunakan data SPBU 44.552.10. Pada penelitian ini sebaran Senyawa pencemar berbahaya yang terkandung dalam BBM seperti Benzen, Toluen, Ethylbenzen Xylen disimulasikan dengan melibatkan proses reaksi, adveksi dan diffusi secara 2 dimensi.

\section{Teori}

Kebutuhan masyarakat akan BBM sangat tinggi, sehingga banyak pengelola menyediakan fasilitas umum untuk memenuhi kebutuhan BBM sepeti SPBU milik Pertamina, Shell, Total,dan Petronas. Untuk melaksanakan kegiatan operasionalnya, maka SPBU dilengkapi sarana dan prasarana utama seperti tangki timbun bawah tanah, jalur pemipaan, mesin dispenser, instalasi listrik, bangunan SPBU, Peralatan proteksi dan pemadam kebakaran, sarana lindung lingkungan, sarana komersial dan tanki timbun. Tangki timbun yang digunakan harus mengikuti Standards Association of Australia: Steel Tanks for the Storage of Flammabe and Combustible Liquids[6]. Ketika tangki timbun telah lama digunakan, 
kemungkinan terjadinya kebocoaran semakin tinggi. Faktor yang menyebabkan kebocoran pada tangki timbun yaitu: kesalahan spesifikasi, bahan tangki tidak kompatibel dengan cairan penigisi, kelebihan tekanan karena pengaruh beban pondasi bagunan atau jalan di sekitar tangki[6]. Dampak kebocoran tangki harus mendapat perhatian serius karena BBM memiki senyawa toksik. Berdasarkan Agency for Toxic Subtances and Diesease Register (ATSDR), senyawa kimia yang bersifat toksik terhadap kesehatan adalah Benzene, Toluene, Ethylbenzene Xylene (BTEX)[7]. Dampak kesehatan yang umum terjadi karena terpapar BTEX, terganggunya sistem syaraf pusat, sistem pernapasan, sistem reproduksi dan lainnya. BTEX secara alami ditemukan dalam minyak mentah dengan konsentrasi $4 \mathrm{gr} / \mathrm{L}$, dalam air laut dengan kosentrasi hingga 0,8 ppm. Sumber BTEX hasil aktifitas manusia meliputi: emisi kendaraan bemotor, kegiatan pemasaran bensin, tumpahan minyak dan lain-lain[8]. Ambang batas konsentrasi BTEX yang ditetapkan bagi kesehatan manusia dapat dilihat pada Tabel 1[9]:

Tabel 1. Ambang Batas Konsentrasi BTEX Ambang Batas Konsentrasi BTEX

\begin{tabular}{lccc}
\hline \multirow{2}{*}{ Kontaminan } & \multicolumn{2}{c}{$\begin{array}{c}\text { Air Minum } \\
\text { (g/L/hari) }\end{array}$} & \multicolumn{2}{c}{ Air Mandi (g/L/hari) } \\
\cline { 3 - 4 } & & Kersentuhan Dengan & $\begin{array}{c}\text { Terhirup Ketika } \\
\text { Kulit }\end{array}$ \\
\hline Benzene & $3,43 \times 10^{-9}$ & $7,38 \times 10^{-10}$ & $4,78 \times 10^{-11}$ \\
Toluene & $7,02 \times 10^{-10}$ & $1,37 \times 10^{-9}$ & $1,12 \times 10^{-11}$ \\
Ethylbenzene & $1,83 \times 10^{-12}$ & $4,88 \times 10^{-12}$ & $2,94 \times 10^{-14}$ \\
xylene & $3,42 \times 10^{-11}$ & $3,66 \times 10^{-13}$ & $6 \times 10^{-13}$ \\
\hline
\end{tabular}

Untuk memprediksi luas wilayah yang tercemar dan konsentrasi BTEX dalam air tanah maka model matematika disusun dengan melibatkan perpindahan kontaminan. Secara lengkap perpindahan kontaminan dalam air tanah dengan melibatkan difusi, adveksi, reaksi dapat dimodelkan secara tiga dimensi seperti persamaan di bawah ini[10].

$$
\begin{aligned}
& \frac{\partial C}{\partial t}+v_{x} \frac{\partial C}{\partial x}+v_{y} \frac{\partial C}{\partial y}+v_{z} \frac{\partial C}{\partial y}=\frac{\partial C}{\partial x}\left(D_{x} \frac{\partial C}{\partial x}\right)+\frac{\partial C}{\partial y}\left(D y \frac{\partial C}{\partial y}\right)+\frac{\partial C}{\partial z}\left(D_{z} \frac{\partial C}{\partial z}\right) \\
& +\sum_{w=1}^{N}\left(C_{O}-C\right) \frac{Q_{W}}{n} \delta\left(x_{w}, y_{w}, z_{w}\right)+\sum R_{\text {reaksi }}
\end{aligned}
$$

Dimana

$$
\begin{array}{ll}
\mathrm{v}_{\mathrm{x}, \mathrm{y}, \mathrm{z}} & =\text { kecepatan dalam arah } \mathrm{x}, \mathrm{y}, \mathrm{z} . \\
\mathrm{D}_{\mathrm{x}, \mathrm{y}, \mathrm{z}} & =\text { difusivitas arah } \mathrm{x}, \mathrm{y}, \mathrm{z} . \\
\mathrm{Q}_{\mathrm{W}} & =\text { laju kebocoran setiap ketebalan ekuifer } \\
\mathrm{n} & =\text { porositas ekuifer } \\
\delta & =\text { dirac delta }(\text { impulse)function } \\
C & =\text { konsentrasi kontaminan } \\
C_{o} & =\text { konsentrasi awal kontaminan } \\
x_{w}, y_{w} & =\text { sumber titik kebocoran } \mathrm{x} \text { dan } \mathrm{y} \\
\mathrm{R}_{\text {reaksi }} & =\text { laju reaksi }
\end{array}
$$

\section{Rancangan Percobaan}

Simulasi pada percobaan ini dilakukan dengan menggunakan data penelitian dari sumber [5], dimana penelitian dilakukan disekitar area SPBU 44.552.10. SPBU 44.552.10 yang pernah 
mengalami kasus kebocoran dan menyebabkan pencemaran air sumur warga disekitarnya. Daerah sebelah selatan, barat dan timur SPBU merupakan pemukiman padat penduduk pengguna air sumur, sehingga menimbulkan dampak sosial yang besar saat terjadi kasus kebocoran bahan bakar minyak. Tangki penyimpanan BBM terdapat kurang lebih $3 \mathrm{~m}$ dari permukaan tanah. Potensi pencemaran BBM terbesar terdapat pada posisi kedalaman $<5 \mathrm{~m}$ dan zarak horizontal $\leq 45 \mathrm{~m}$ dan potensi pencemaran BBM dengan tingkat sedang terdapat pada posisi kedalaman >3-3.5m dan zarak horizontal >45-200m seperti pada Gambar 1 [5].

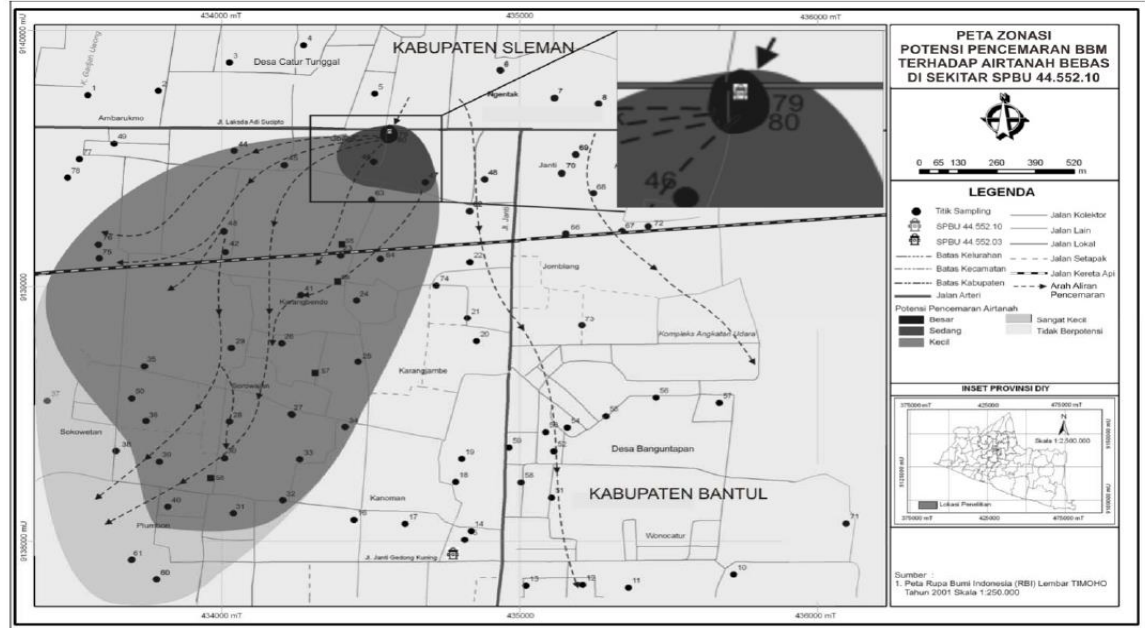

Gambar 1. Peta Zonasi Potensi Pencemaran BBM Terhadap Air Tanah Bebas di Sekitar SPBU 44.552.10 [5]

Sebaran spasial kedalaman muka air tanah menunjukan kedalaman sumur-sumur yang terdekat dari SPBU 44.552.10 bekisar 0-6 m. Jenis media zona tak jenuh (aktifer) pada keadalaman $<5 \mathrm{~m}$ adalah pasir kasar dengan kecepatan aliran air tanah berkisar 0,0339 $\mathrm{m} / \mathrm{hari}$ hingga $0,1516 \mathrm{~m} /$ hari. Berdasarkan keterangan di atas kita dapat memodelkan kebocoran BBM pada SPBU 44.552.10 seperti pada Gambar 2 dan 3.

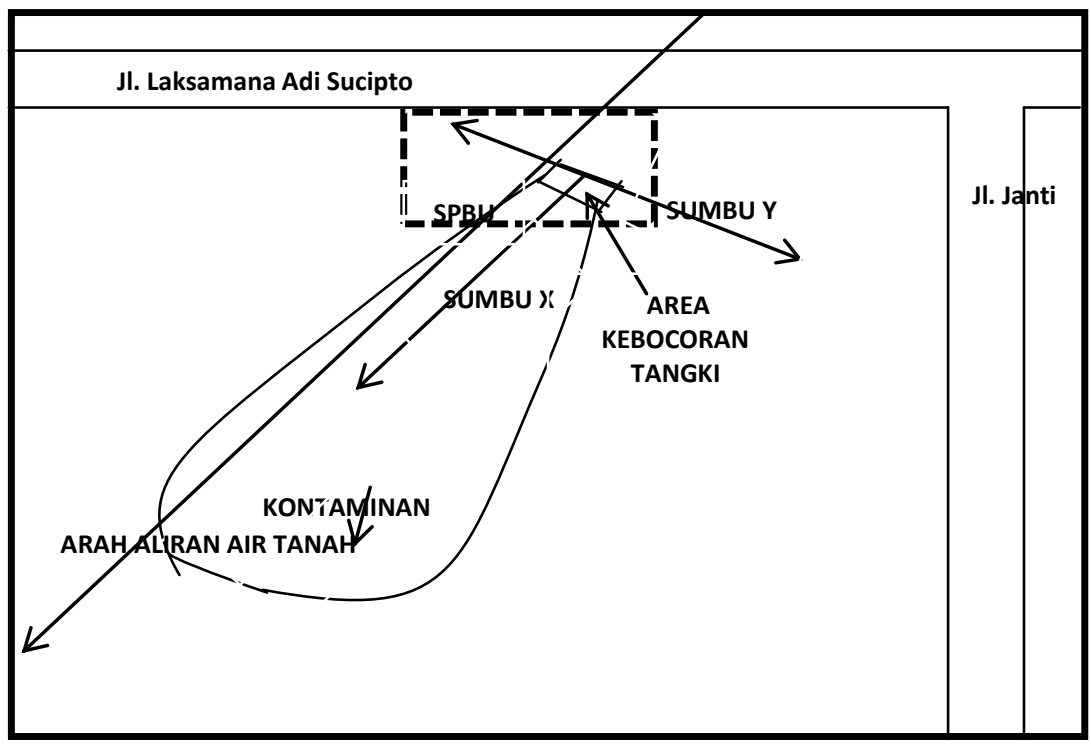

Gambar 2. Sketsa Penyebaran Kontaminan pada Sumbu x dan y 


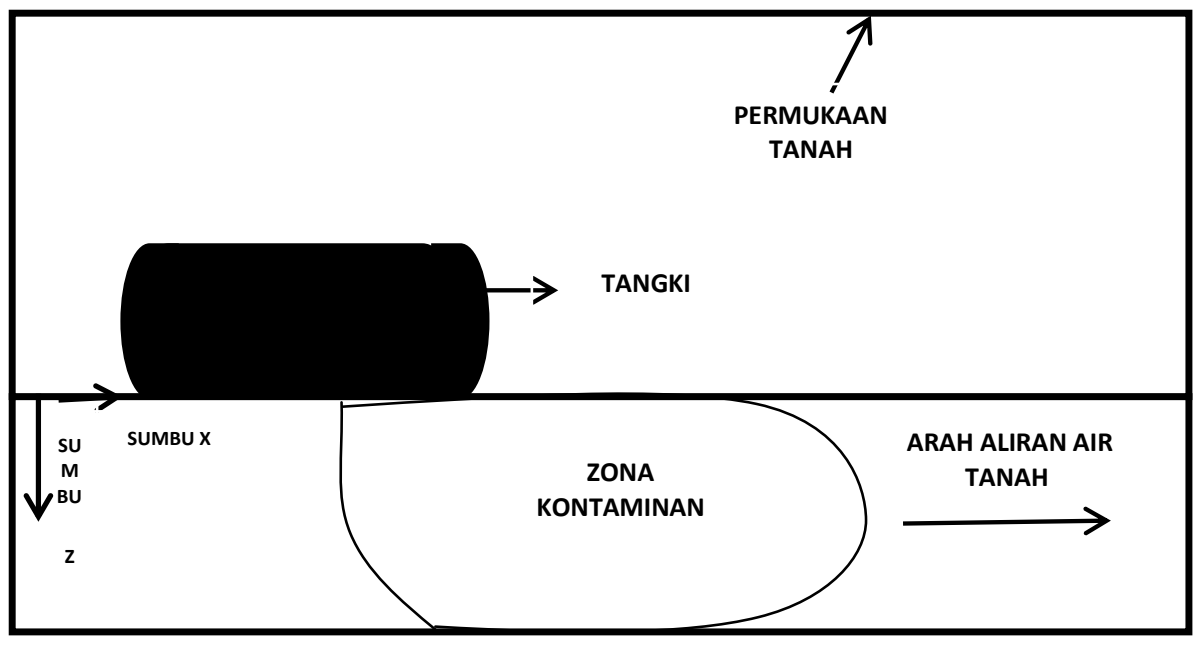

Gambar 3. Sketasa Penyebaran Kontaminan pada sumbu x dan z

Untuk menyederhanakan persamaan maka diambil asumsi sebagai berikut:

1. Kandungan ekuifer pada kelaman $<6$ meter berupa pasir kasar dan bersifat homogen sehingga model yang terbentuk adalah dua dimensi.

2. Densitas dan viskositas fluida konstan

3. Reakasi yang terjadi adalah orde satu

4. Aliran hanya terjadi pada arah sumbu $x$ dengan kecepatan konstan

5. Koefisien Diffusifitas terhadap sumbu x dan y adalah konstan

6. Kebocoran tangki sudah berlangsung lama dan steady state

Dari asumsi di atas maka persamaan satu dapat disederhanakan menjadi persamaan 2.

$$
v \frac{\partial C}{\partial x}=\frac{\partial}{\partial x} D_{x} \frac{\partial C}{\partial x}+\frac{\partial}{\partial y} D_{y} \frac{\partial C}{\partial y}-\lambda C+\frac{Q_{w}}{n} C_{o} \delta\left(y-y_{w}, x-x_{w}\right) \delta
$$

diamana $\chi$ adalah konstanta laju biodegradasi, dan kondisi awal seperti pada persamaan 3

saat $C=0,-\infty<y<+\infty,-\infty<x<+\infty$

dan kondisi batas seperti pada persamaan 4 dan 5

$$
\begin{aligned}
& \frac{\partial C}{\partial y}=0 ; y= \pm \infty \\
& \frac{\partial C}{\partial x}=0 ; x= \pm \infty
\end{aligned}
$$

persamaan 2-5dapat diselesaikan secara analitis menjadi persamaan 6 [11] , 


$$
C(x, y)=\frac{Q_{w} C_{0} \exp \left[\frac{v\left(x-x_{w}\right)}{2 D_{x}}\right]}{2 n \pi \sqrt{D_{x} D_{y}}} K_{0}\left\{\sqrt{\left(\frac{v^{2}}{4 D_{x}}+\lambda\right)\left[\frac{\left(x-x_{w}\right)^{2}}{D_{x}}+\frac{\left(y-y_{w}\right)^{2}}{D_{y}}\right]}\right\}
$$

Pada penelitian ini data parameter fisik dapat dilihat pada Tabel 2.

Tabel 2. Data Parameter Fisik

\begin{tabular}{lll}
\hline Farameter & Nilai & Sumber \\
\hline Kelarutan Maksimum dalam air tanah: & & \\
Benzen & $10.000\left(\mu \mathrm{g} \mathrm{L}^{-1}\right)$ & {$[9]$} \\
Toluen & $22.000\left(\mu \mathrm{g} \mathrm{L}^{-1}\right)$ & {$[9]$} \\
Ethylbenzen & $3.100\left(\mu \mathrm{g} \mathrm{L}^{-1}\right)$ & {$[9]$} \\
Xylen & $20.000\left(\mu \mathrm{g} \mathrm{L}^{-1}\right)$ & {$[9]$} \\
Diffusi ke arah sumbu x $\left(\mathrm{D}_{\mathrm{x}}{ }^{*}\right):$ & & \\
Benzen & $0,0166 \mathrm{~m}^{2}$ hari $^{-1}$ & {$[9]$} \\
Toluen & $0,0123 \mathrm{~m}^{2}$ hari $^{-1}$ & {$[9]$} \\
Ethylbenzen & $0,0082 \mathrm{~m}^{2}$ hari $^{-1}$ & {$[9]$} \\
Xylen & $0,009 \mathrm{~m}^{2}$ hari $^{-1}$ & {$[9]$} \\
Diffusi ke arah sumbu y $\left(\mathrm{D}_{\mathrm{y}}{ }^{*}\right):$ & & \\
Benzen & $0,00167 \mathrm{~m}^{2}$ hari $^{-1}$ & {$[9]$} \\
Toluen & $0,0012 \mathrm{~m}^{2}$ hari $^{-1}$ & {$[9]$} \\
Ethylbenzen & $0,0009 \mathrm{~m}^{2}$ hari $^{-1}$ & {$[9]$} \\
Xylen & $0,0024 \mathrm{~m}^{2}$ hari $^{-1}$ & {$[9]$} \\
Laju biodegradasi & & \\
Benzen & $0,0001 \mathrm{hari}^{-1}$ & {$[9]$} \\
Toluen & $0,0001 \mathrm{hari}^{-1}$ & {$[9]$} \\
Ethylbenzen & 0,0001 hari $^{-1}$ & {$[9]$} \\
Xylen & 0,0001 hari $^{-1}$ & {$[9]$} \\
Kecepatan aliran air tanah di Yogyakarta & $0,0003 \mathrm{~m} \mathrm{hari}^{-1}$ & {$[5]$} \\
Porositas pasir kasar & 0,39 & {$[12]$} \\
\hline
\end{tabular}

Variabel yang akan disimulasikan pada penelitian ini adalah besarnya debit kebocoran tangki (50 - 500 L/hari), kecepatan aliran tanah (0,0339 - 0,1516 m/hari), luas kebocoran tangki (1 $250 \mathrm{~cm}^{2}$ ). Algoritma yang dibentuk untuk simulasi pada penelitian ini adalah sebagai berikut: 
Jurnal Teknologi, Tahun 2018, Volume 6, Edisi 1

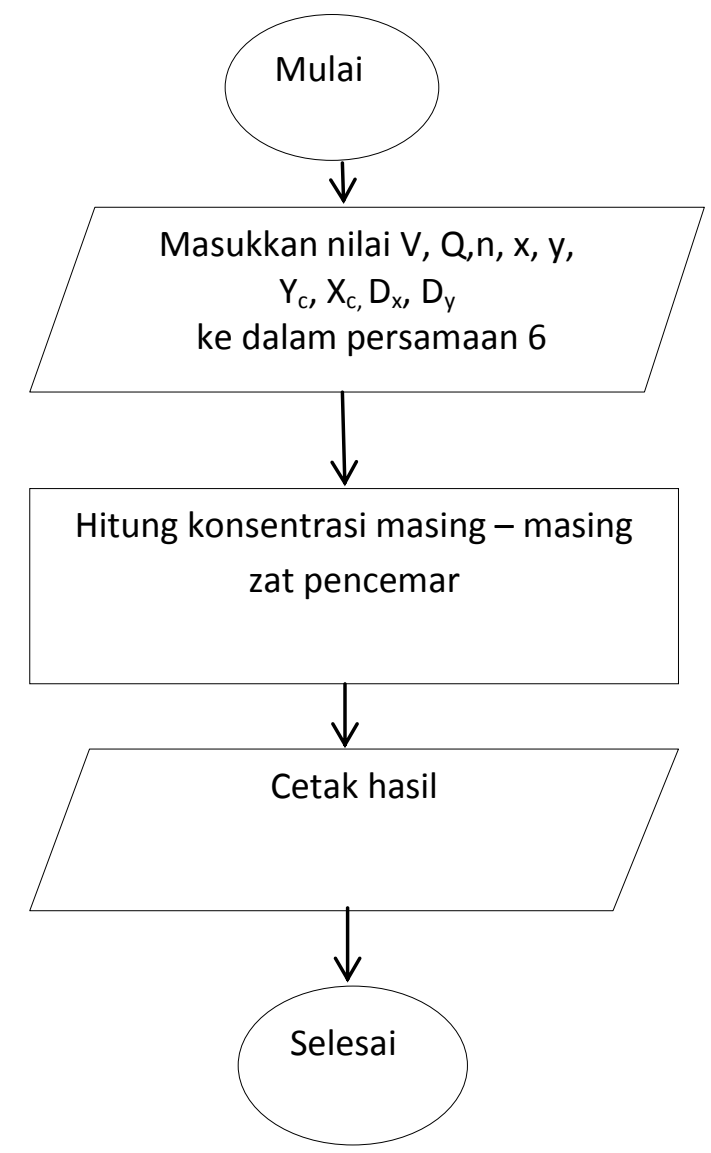

Gambar 3. Algoritma Perhitungan Konsentrasi Kontaminan 


\section{Hasil dan Pembahasan}

\subsection{Simulasi Pengaruh Debit Kebocoran BBM Terhadap Sebaran Kontaminan}

Pada penelitian disimulasikan sebaran konsentrasi Benzen pada daerah sekitar tangki timbun. Debit kebocoran pada tangki timbun BBM divariasikan mulai dari 25 - 75 L/ hari dimana kondisi kecepatan aliran air tanah sebesar $0,1516 \mathrm{~m} /$ hari dan luas kebocoran tangki sebesar 1 $\mathrm{cm}^{2}$. Profil sebaran konsentrasi Benzen dapat dilihat pada Gambar 4,5 dan6.

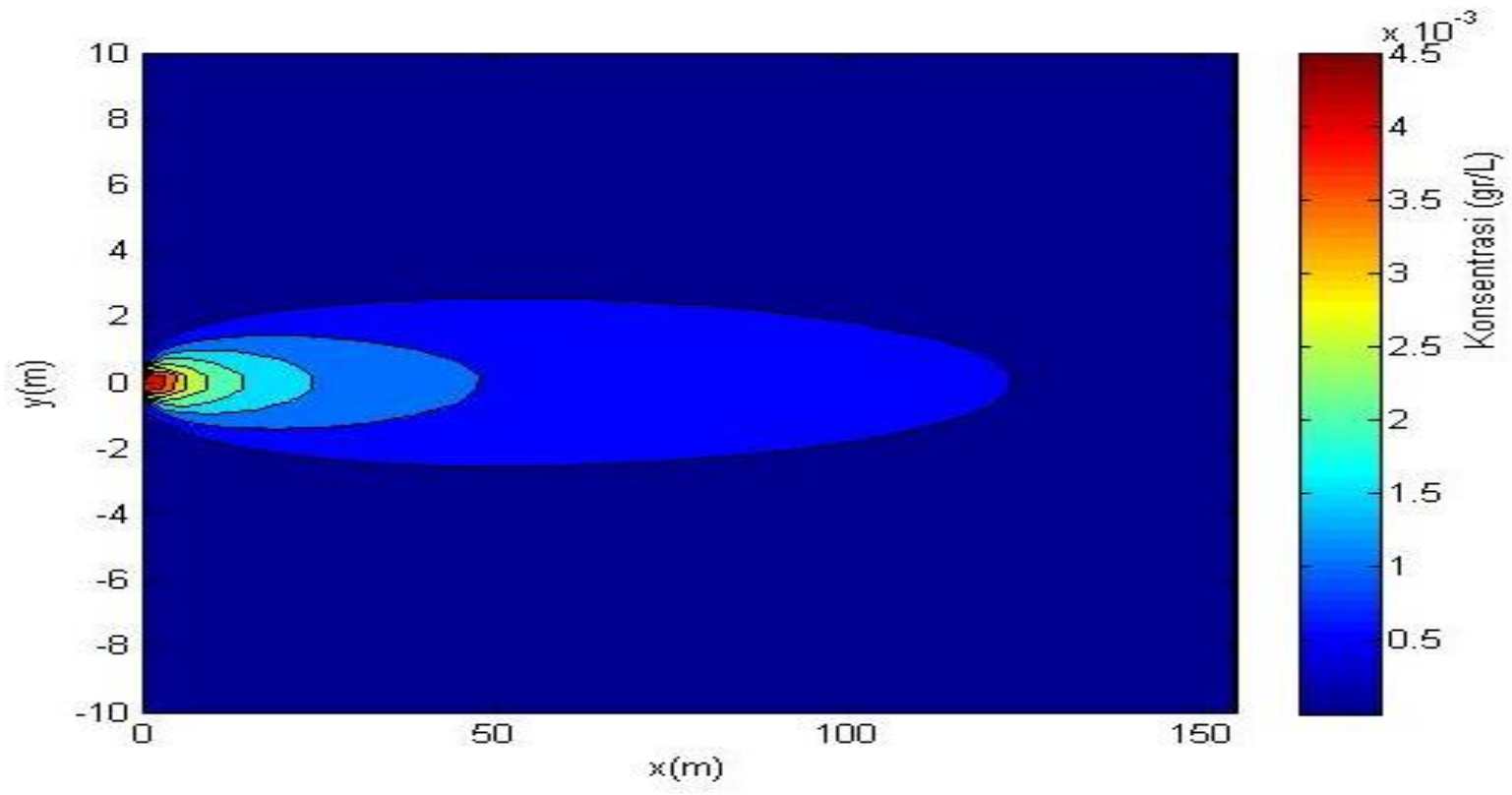

Gambar 4. Simulasi Sebaran Konsentrasi Benzen pada Arah x dan y dengan Q = 25 L/hari

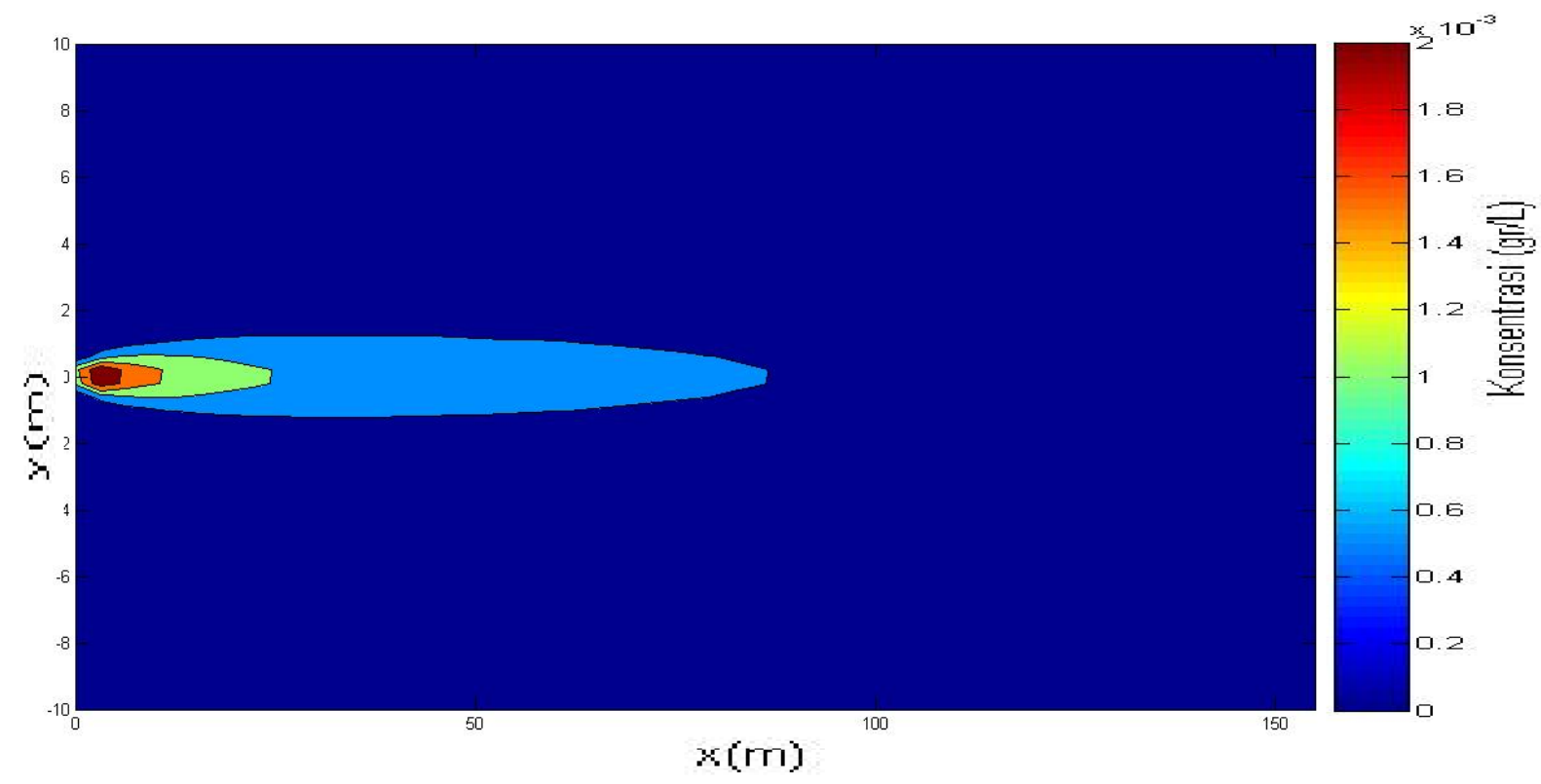

Gambar 5. Simulasi Sebaran Konsentrasi Benzen pada Arah x dan y dengan Q = 50 L/hari 


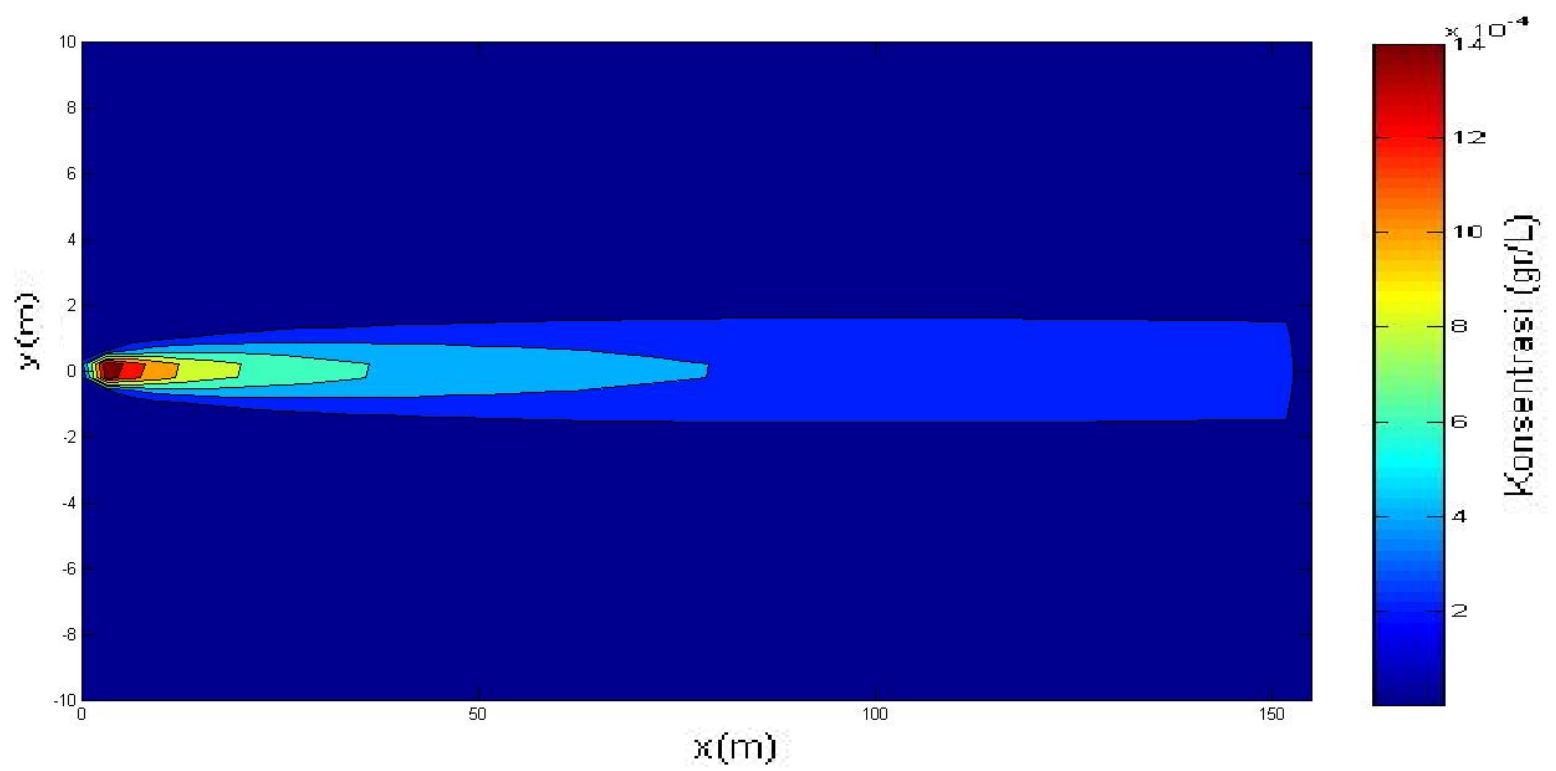

Gambar 6. Simulasi Sebaran Konsentrasi Benzen pada Arah x dan y dengan Q = 75 L/hari Pada Gambar 4,5,dan 6 profil sebaran konsentrasi Benzen meningkat seiring meningkatnya debit kebocoran pada tangki timbun. Konsentrasi Benzen pada posisi terjauh $(\mathrm{x}=150 \mathrm{~m}$, $\mathrm{y}=0,2 \mathrm{~m}$ ) dengan debit kebocoran $25 \mathrm{~L} /$ hari adalah sebesar $0.00028 \mathrm{gr} / \mathrm{L}$, hal ini menunjukan bahwa air tanah yang berada pada area seluas $\pm 560 \mathrm{~m}^{2}$ berbahaya apabila digunakan sebagai air minum dan air untuk mandi. Seperti yang ditunjukkan pada Tabel 1, konsentrasi Benzen yang di izinkan untuk air minum dan air mandi adalah sebesar $7,38 \times 10^{-10} \mathrm{gr} / \mathrm{L}$ dan $4,78 \times 10^{-}$ ${ }^{11} \mathrm{gr} / \mathrm{L}$.

\subsection{Simulasi Pengaruh Luas area Kebocoran Tangki Timbun Terhadap Sebaran Kontaminan}

Luas area kebocoran tangki turut mempengaruhi sebaran konsentrasi Benzen seperti pada Gambar 7 dan 8 . Luas area kebocoran tangki divariasikan dari $1-250 \mathrm{~cm}^{2}$, dimana konsentrasi sebaran Benzene akan meningkat hingga jarak maksium $150 \mathrm{~m}$ pada arah sumbu $\mathrm{x}$.

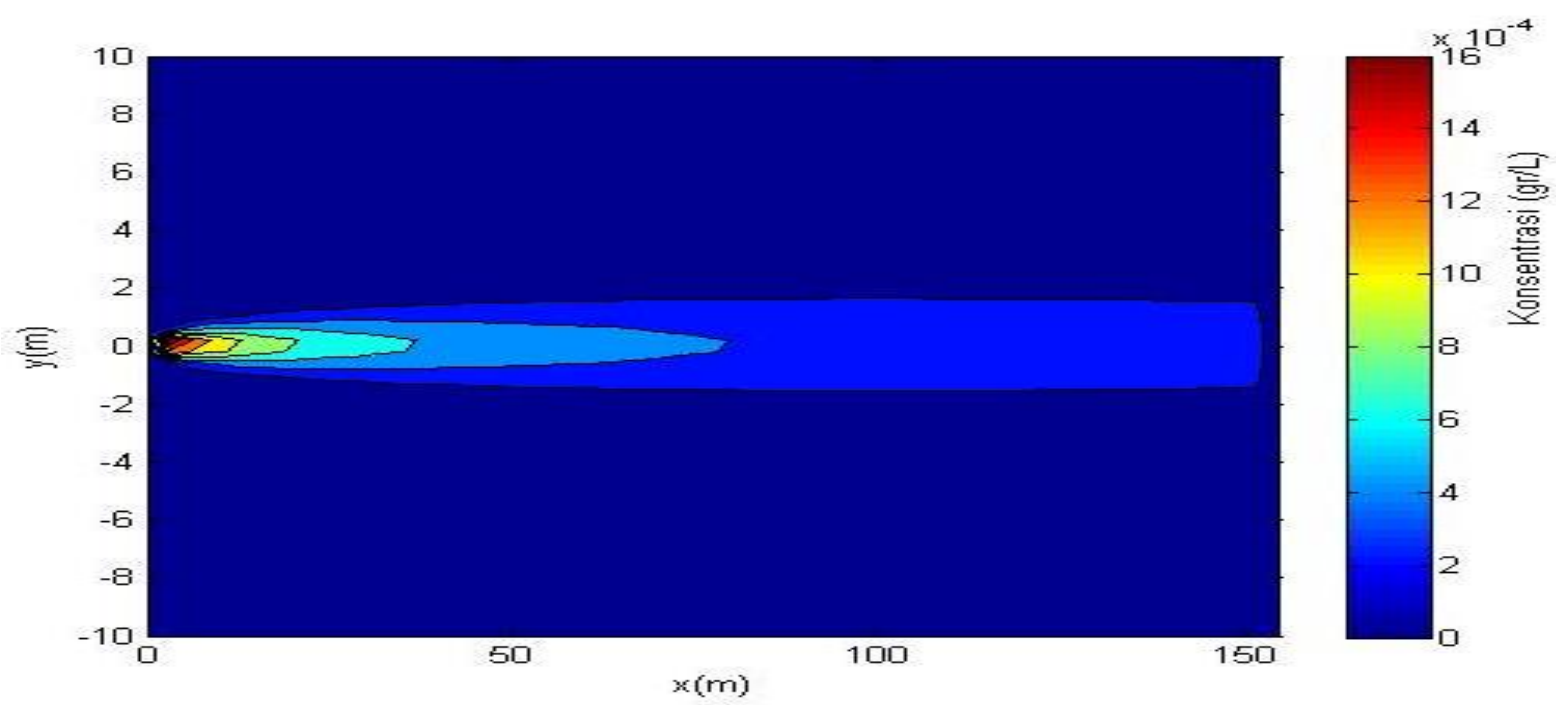

Gambar 7. Simulasi Sebaran Konsentrasi Benzen dengan Luas Kebocoran $1 \mathrm{~cm}^{2}$ 


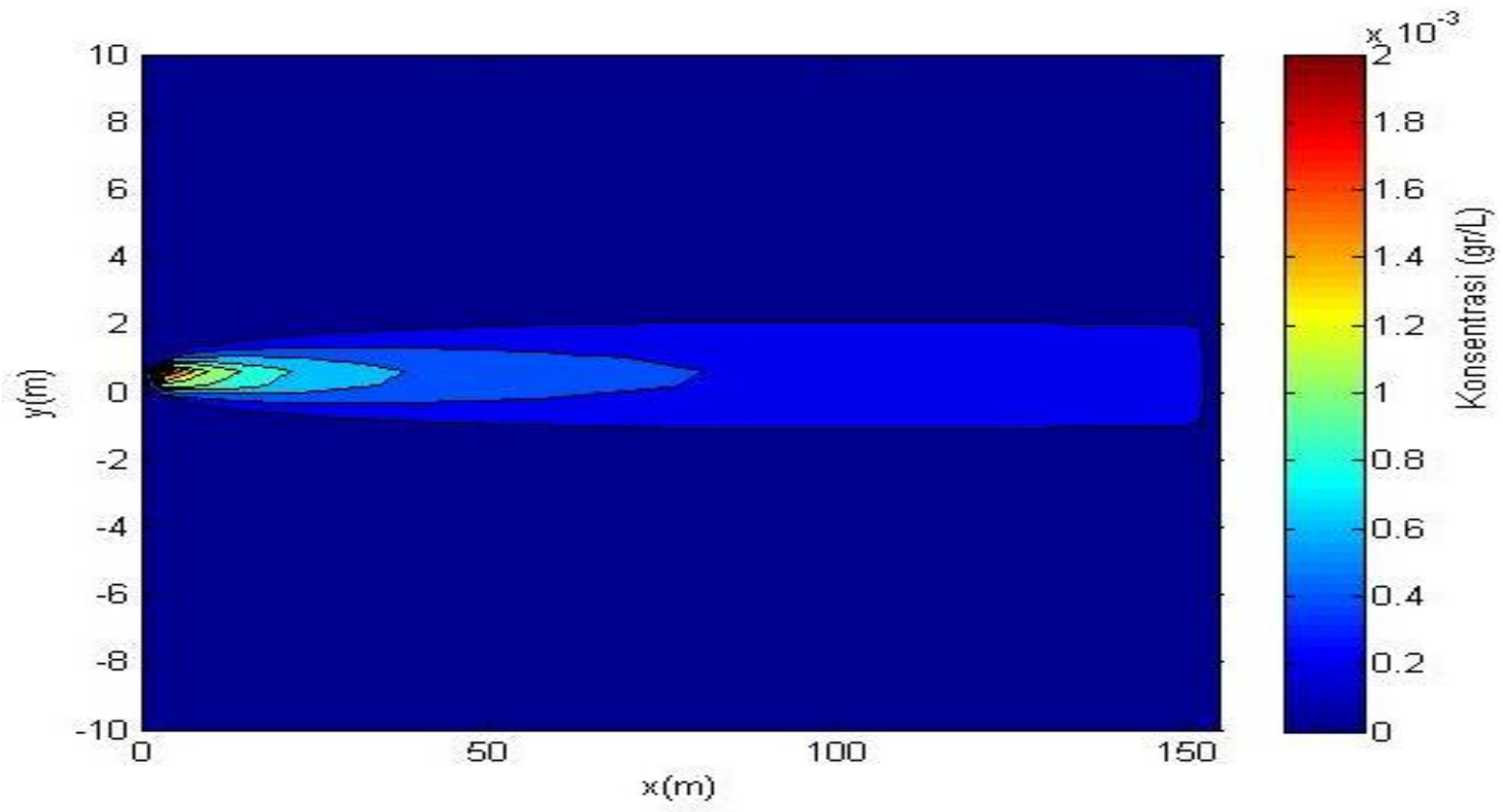

Gambar 8. Simulasi Sebaran Konsentrasi Benzen dengan Luas Kebocoran $250 \mathrm{~cm}^{2}$

\subsection{Simulasi Pengaruh Kecepatan Aliran Air Tanah Terhadap Sebaran Kontaminan}

Kecepatan air tanah tidak mempengaruhi luas area sebaran konsentrasi Benzen, luas area yang terkontaminasi Benzen adalah seluas $\pm 560 \mathrm{~m}^{2}$. Dari Gambar 9 dan10 dapat dilihat konsentrasi sebaran Benzen akan meningkat dengan meningkatnya kecepatan aliran air tanah.

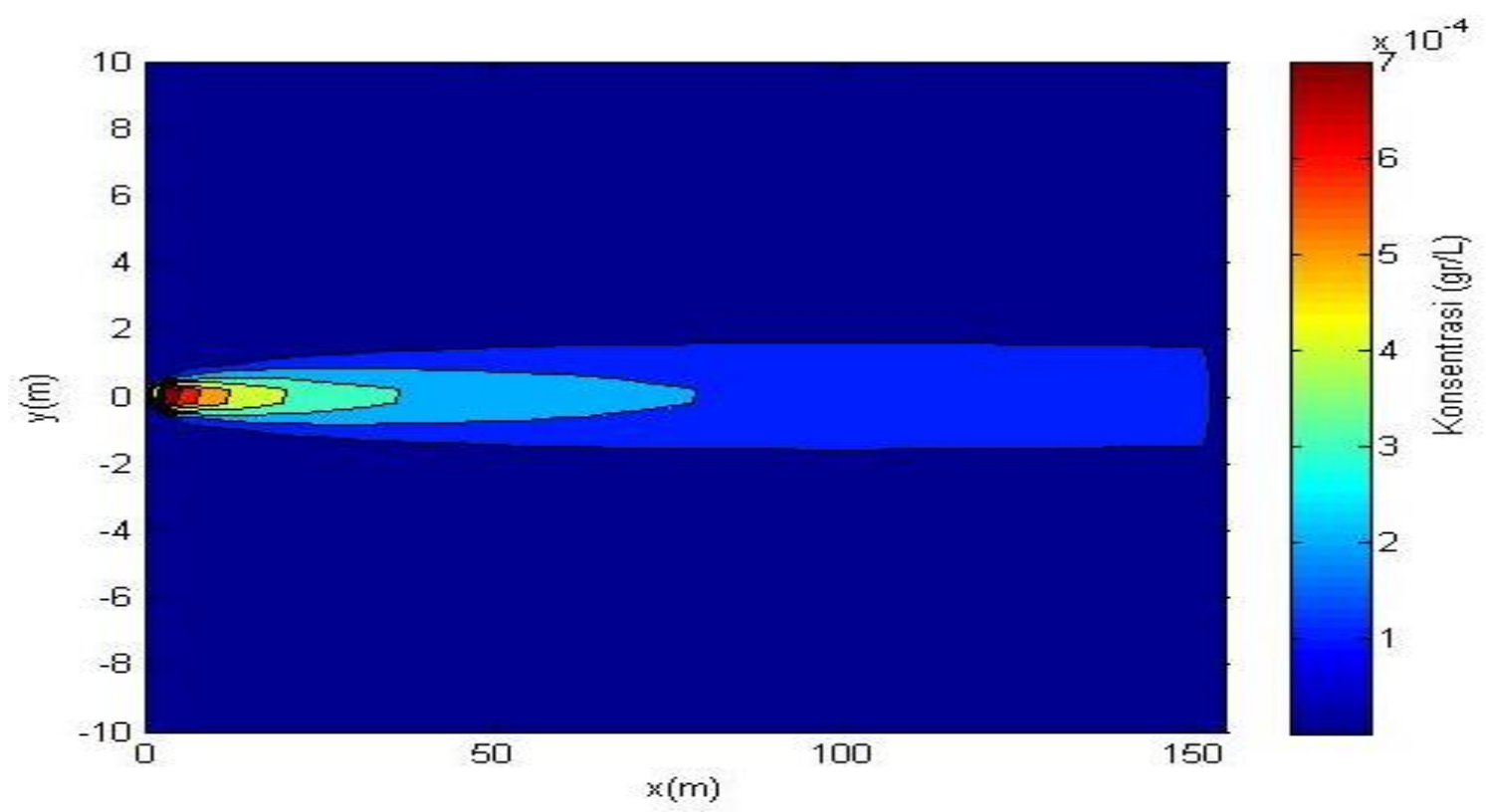

Gambar 9. Simulasi Sebaran Konsentrasi Benzen dengan v =0.0339 m/hari 


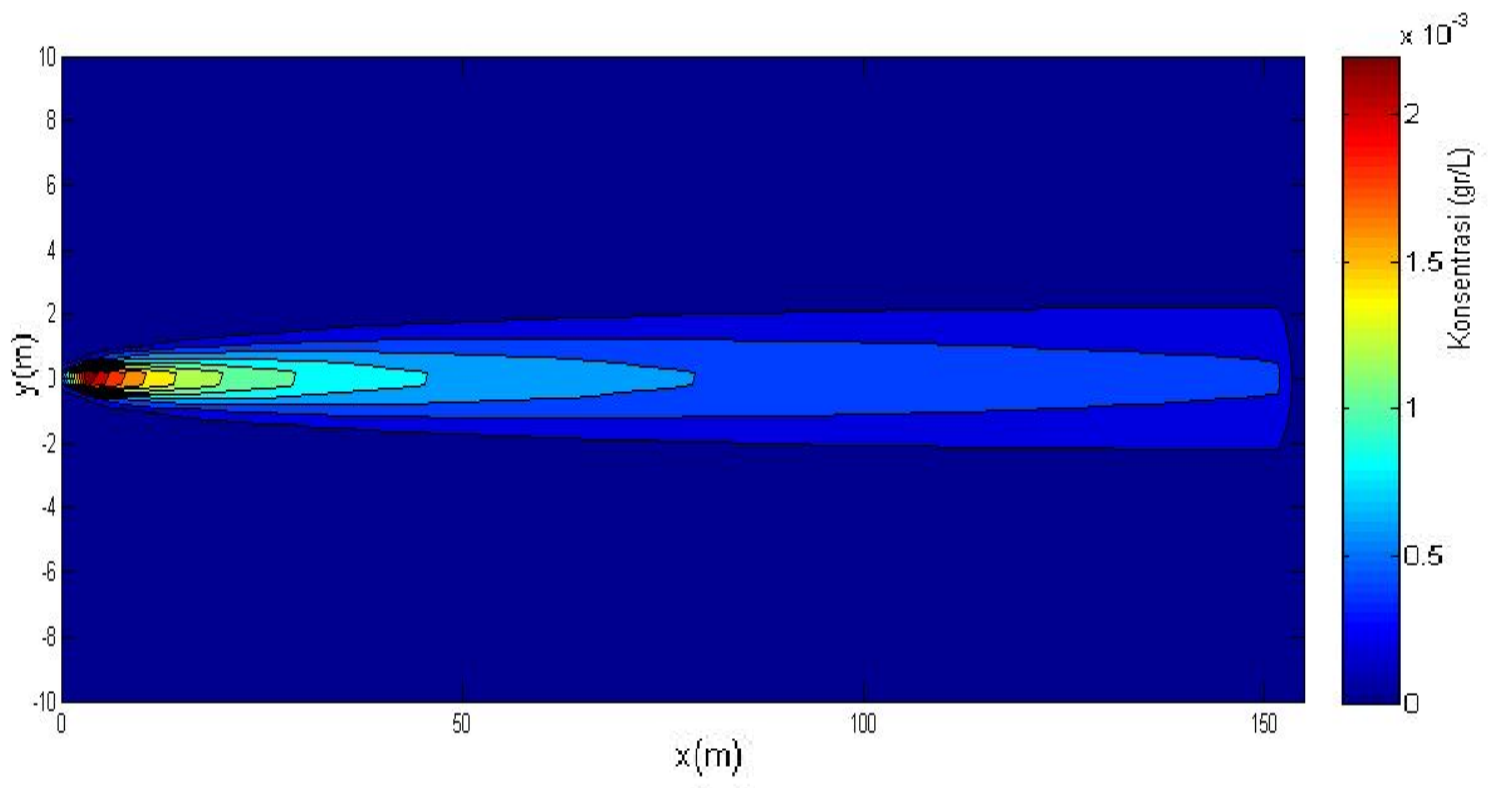

Gambar 10. Simulasi Sebaran Konsentrasi Benzen v =0.08m/hari

\subsection{Simulasi Sebaran Berbagai Kontaminan}

Selain senyawa Benzen, senyawa Toluen, Ethylbenzen, Xylan turut di simulasikan pada penelitian ini, seperti pada Gambar 11,12, dan 13. Luas area sebaran konsentrasi setiap senyawa berbeda beda, luas area sebaran konsentrasi Toulen adalah $\pm 354 \mathrm{~m}^{2}$, Ethylbenzen adalah $\pm 234 \mathrm{~m}^{2}$, xylen adalah $\pm 336 \mathrm{~m}^{2}$. Pada daerah tersebut air tanah tidak layak digunakan sebagai air minum dan air unuk mandi. Salah satu solusi yang dapat digunakan untuk menangani pencemaran BTEX ini yaitu dengan cara bioremediasi[13].

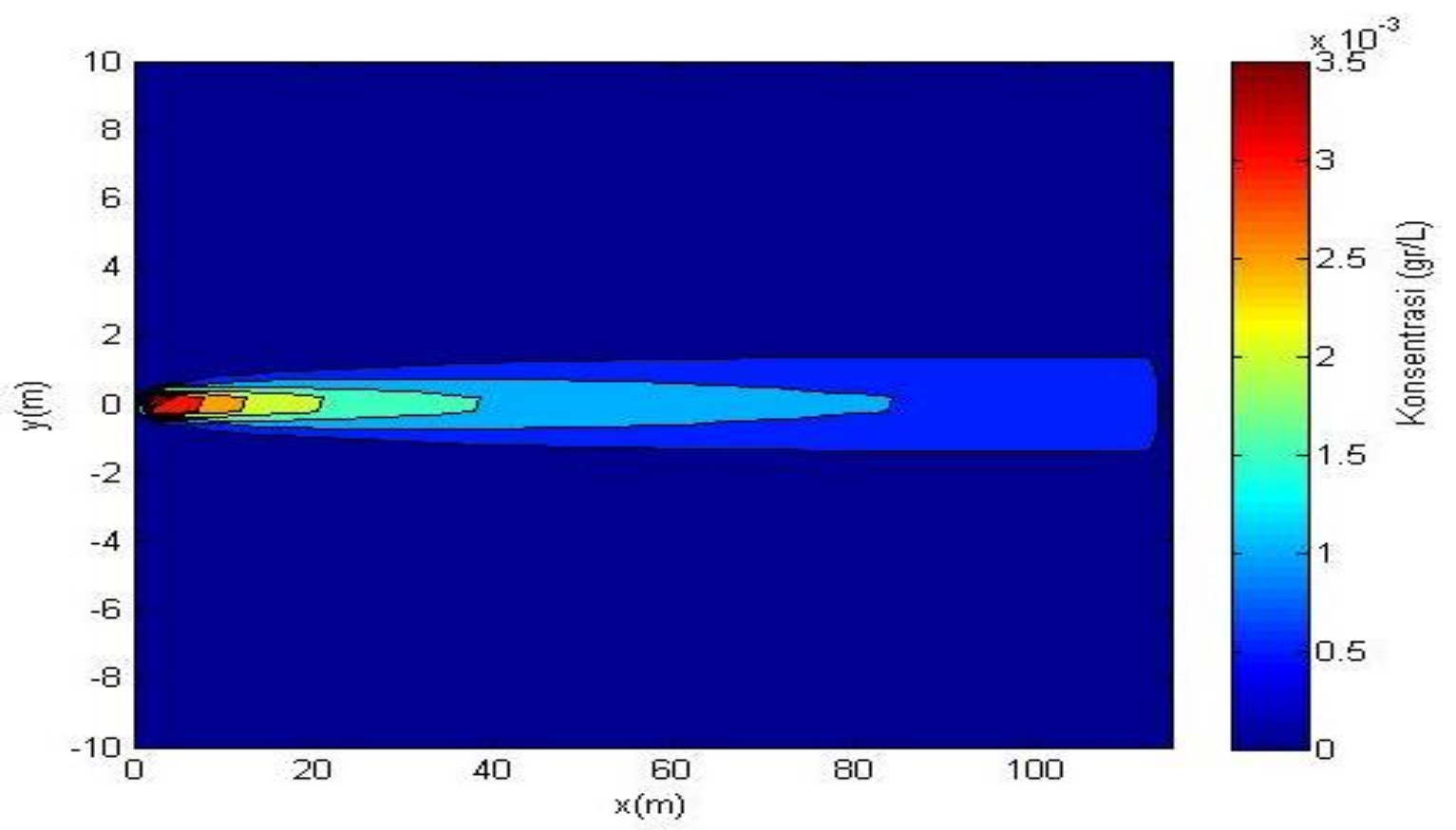

Gambar 11. Simulasi Sebaran Konsentrasi Toluen pada Arah x dan y 


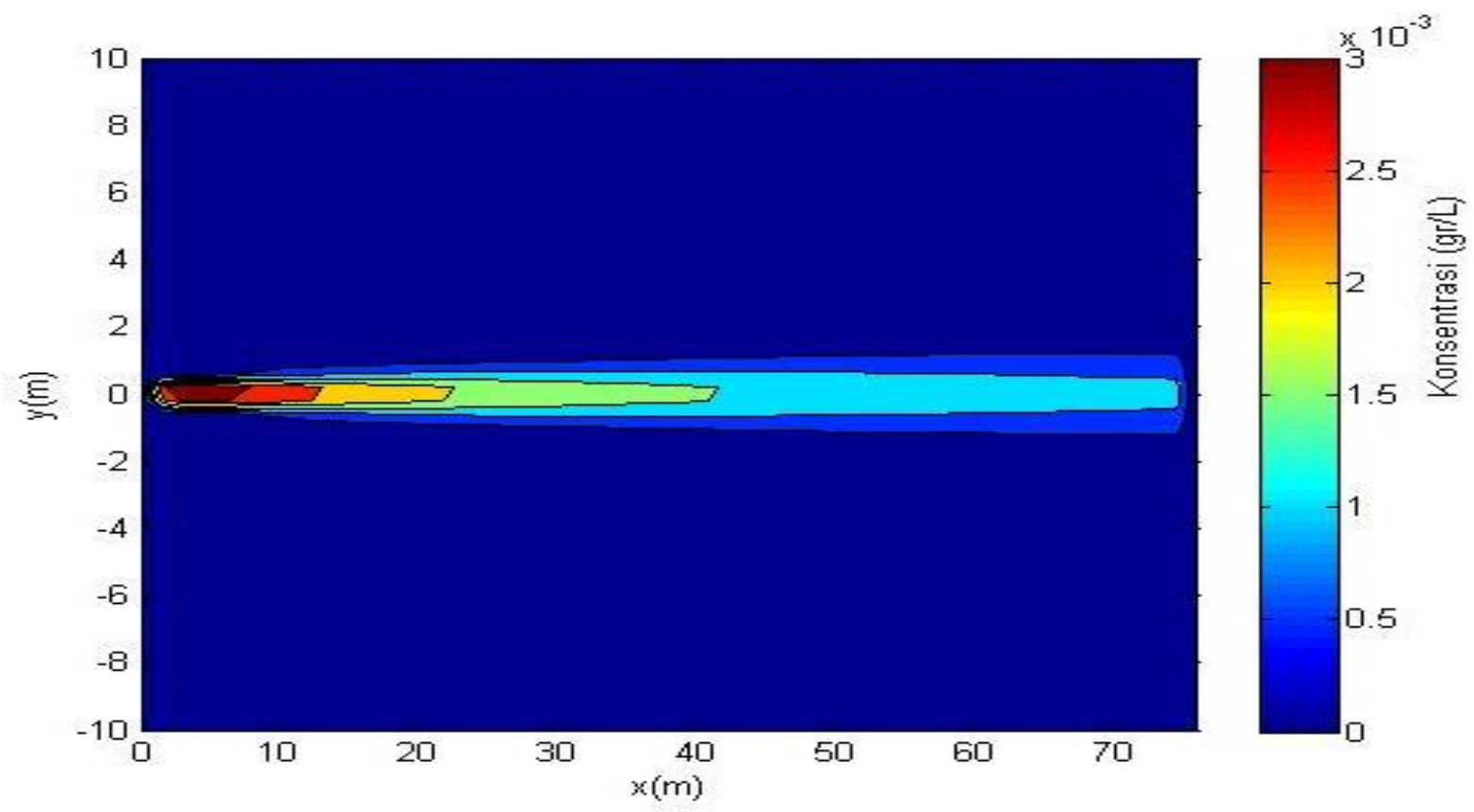

Gambar 12. Simulasi Sebaran Konsentrasi Ethylbenzen pada Arah x dan y

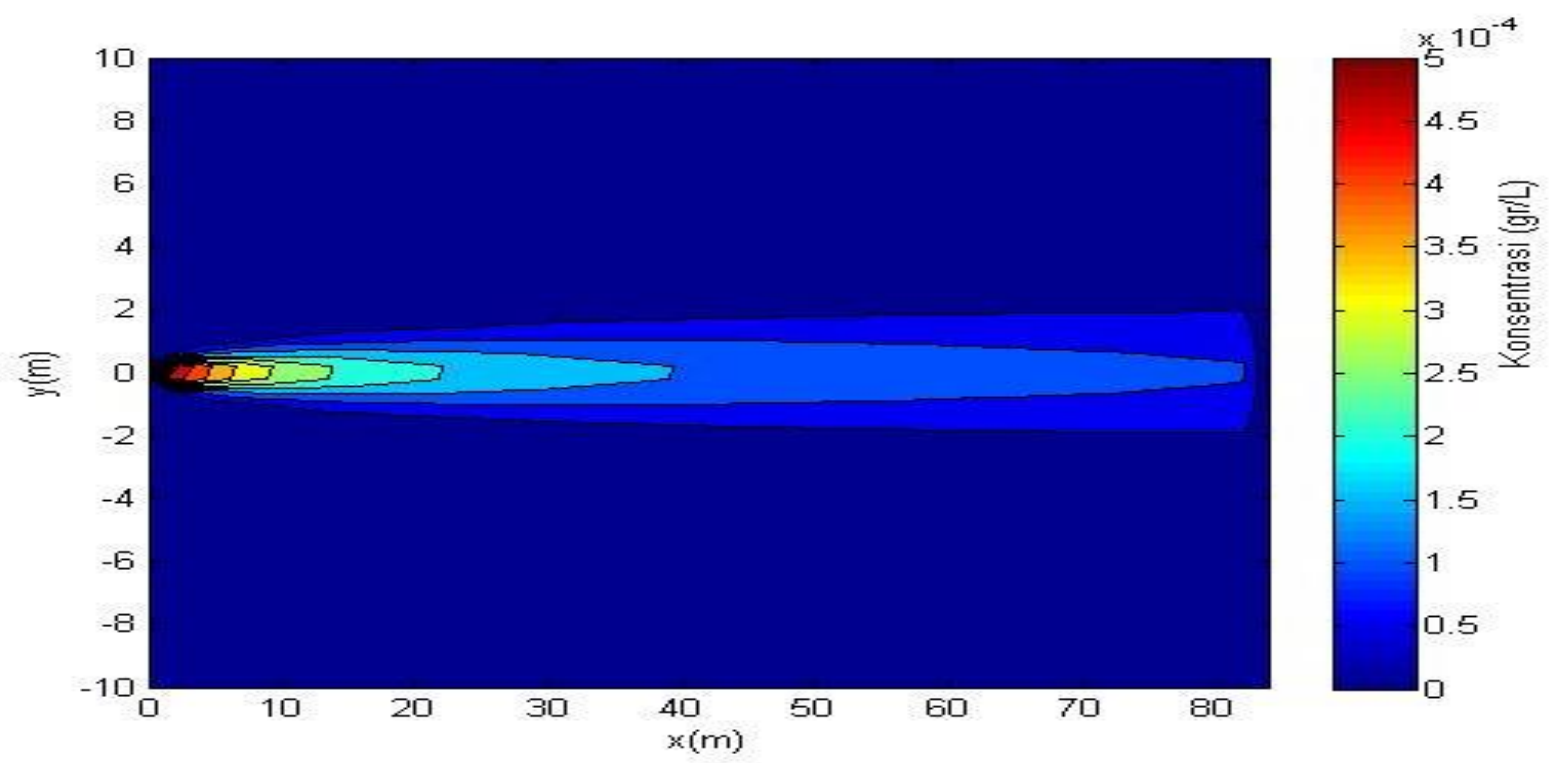

Gambar 13. Simulasi Sebaran Konsentrasi Xylen pada Arah x dan y

\section{Kesimpulan}

Pada penelitian ini dapat disimpulkan bahwa variabel seperti debit kebocoran, luas kebocoran tangki timbun dan kecepatan aliran air tanah tidak mempengaruhi luas area yang tercemar namun variabel tersebut mempengaruhi konsentrasi kontaminan di setiap area. Luas area yang tercamar Benzen adalah $\pm 560 \mathrm{~m}^{2}$, Toluen adalah $\pm 354 \mathrm{~m}^{2}$, Ethylbenzen adalah \pm $234 \mathrm{~m}^{2}$, Xylen adalah $\pm 336 \mathrm{~m}^{2}$. Pada luas area tersebut air tanah tidak layak konsumsi. Peneliti merekomendasikan untuk memvalidasi hasil simulasi dengan data hasil analisis konsentrasi BTEX pada sempel air tanah di dilapangan. 


\section{Daftar Pustaka}

[1] Sulfahri, Mohamad A, Sutiman, B.S, Murni,S. Bioetanol Alga Spirogyra Bahan Bakar Masa Depan, Leutikaprio. 2016, Indonesia, 1

[2] Mukhopadhay, K and Forssell. " An empirical investigation of air pollution from fossil fuel combustion and its impact on helth in india during 1973-1974 to 1996-1997'. Ecological Economics, Vol. 55, 2005, 235-250.

[3]. Euan, M," State of emergency declared over Indonesia oil spill, CNN, 5, April 2018, [Online], Tersedia : https://edition.cnn.com/2018/04/04/asia/indonesia-balikpapan-oilspill-state-of-emergency/index.html. [diakses 10, Agustus 2018].

[4]. Indara, S.A.P, "Analisis pencemaran hidrokarbon dari bahan bakar minyak bensin terhadap airtanah di sekitar stasiun pengisian bahan bakar umum". DSpasce UII. [Online],Tersedia:https://dspace.uii.ac.id/bitstream/handle/123456789/2692/08\%20naska h\%20publikasi.pdf?sequence=14\&isAllowed=y. [diakses 10, Agustus 2018].

[5]. Eni, M, “Zonasi potensi pencemaran bahan bakar minyak terhadap air tanah bebas (studi kasus SPBU 44.552.10 yogyakarta)". Jurnal Sains dan Teknologi Lingkunagan, Vol. 4, $2012,114-124$.

[6] Hery S, "Studi penyusunan sistem pemeringkatan "safe"(Safety assessment of fire and explosion) untuk menilai tingkat keselamatan terhadap kebakaran dan ledakan di stasiun pengisian bahan bakar umum (SPBU)”, Tesis, Universitas Indonesia, Depok, 2012.

[7] U.S. Department of Health and Human Services Public Health Service Agency for Toxic Substances and Disease Registry," INTERACTION PROFILE FOR: Benzene, Toluene, Ethylbenzene, and Xylenes (BTEX)",2004.

[8] Abdul R, Ni,M.S , Wiwik, S.R, Analisis fenol dalam urin pekerja salah satu stasiun pengisian bahan bakar umum di kota Denpasar”. Jurnal Kimia. Vol. 9. 2015. 105-108

[9] David,J.C and Stephen D.B, Ground water modeling for Risk Assessment Purposes: Use of a Gaussian-Distributed Transport Model and a Batch Flush Model.

[10] Mustafa,M.A," Environmental Modeling and Health Risk Analysis (Acts/Risk)”, Spinger, 2010, USA 218.

[11] Wexler, E.J, Analytical solutions for one-, two-, and three-dimensional solute transport in groundwater systems with uniform flow, Techniques of Water-Resources Investigations of the United States Geological Survey, Book 3, 1992, 27.

[12] Puguh, D., Ig.L. Setyawan, P, Analisis karakteristik dan potensi akuifer kecamatan purworejo kabupaten purworejo dengan metode vertical electrical sounding (VES). Jurnal Bumi Indonesia, Vol.7, 2018. 
Jurnal Teknologi, Tahun 2018, Volume 6, Edisi 1

[13] Marsya,D.P., Firadus,A and Zulkifliani, Bioremediasi tanah yang terkontaminasi minyak bumi dengan metode bioventing terhadap penurunan kadar total petroleum hydrocarbon dan BTEX, 20 